\title{
New Evangelization Practices? Devotional Prayer, Meetings, and Christian Service
}

\author{
Michael J. McCallion ${ }^{1, *}$, Sacred Heart Major Seminary ${ }^{2}$, Detroit MI ${ }^{3}$ \\ School of Theology, Rev. William Cunningham Chair in Catholic Social Analysis, USA
}

Copyright $\bigcirc 2017$ by authors, all rights reserved. Authors agree that this article remains permanently open access under the terms of the Creative Commons Attribution License 4.0 International License

\begin{abstract}
Conscious of the disciplinary turn away from examining predominantly cognitive, belief, and rational factors to examining emotional, bodily, and ritual factors this research focused on what people were "doing" in relation to the New Evangelization (NE) and less on what they were saying. Consequently, three general categories of doings/activities are described that are associated with the NE. Although associated with the NE, can these doings actually be called NE practices per se? Or, is the NE retrospectively theologically legitimizing Catholic practices already in place? Focusing on "practices", therefore, Rawls [1] raised not only the question, are there NE practices, but also the Durkheimian epistemological question of the relationship between enacted practices and beliefs/ideas. Although this is not the place to address the Durkheimian epistemological question, it was found that the NE was retrospectively legitimizing Catholic practices already in place rather than creating new practices. Moreover, this research has revealed over time that the $\mathrm{NE}$ in its initial stages (2005-2012) infused a more individualistic and emotional emphasis to the Catholic practices of devotional prayer and NE parish meetings to emphasize a more communal/ecclesial dimension in Christian service practices. Although further research is needed, it appears that Christian service/communal practices already in place are receiving the same fueling of emotional vigor that the more individualistically oriented practices of devotions and meetings received from the theology of the NE.
\end{abstract}

Keywords New Evangelization, Durkheim, Enacted Practices, Christian Service

\section{Introduction}

What one person or group associates with the words 'the new evangelization' is often both similar and different from what others will associate with them. But then there is reality. And while the relation between words and reality is complicated, most people will not deny that ultimately it is reality that people care most about when trying to figure out what is going on in a given situation. Elsewhere, the complexity of the term "New Evangelization" as a powerful, flexible word-symbol (technically a "sign" or ideograph) that has become one of the most important in the contemporary Roman Catholic church since the Second Vatican Council has been addressed (see[2],[3]). And while words are a very important, indeed a crucial part of human reality, to get at understanding the NE at a deeper and more comprehensive level, focusing more specifically on what people are actually doing is necessary. This means turning attention to not only theological and pastoral statements about the NE, but also focusing on what people "on the ground" are doing in their everyday lives. This conscious turning away from examining predominantly cognitive, belief, and rational factors to examining emotional, bodily, and ritual factors (or mind to body, texts to performances, ideas to practices), is being widely advocated by many sociologists of religion[4]. Hence, our field work focused on what people were "doing" in relation to the NE and less on what they were saying.

The attention to what people are actually doing is especially important because the $\mathrm{NE}$ as a word-symbol (cognitive) has been mostly emphasized among some leaders of the Catholic Church. While some look to its passing as a fad or declining buzzword, as of 2013 its cache was as strong as ever given Pope Francis's apostolic exhortation Evangelii Gaudium[5]. The exhortation begins and ends and is therefore framed by the notion of the NE. The details, twists and turns of what that actually looks like in terms of the Gospel, the church's mission, the legacies of previous popes, the legacy of Vatican II, and the social teachings of the church are explored elsewhere [6] but the turn of that language toward a larger sense of the social teachings of the church, something new, intensified the importance of looking at the practices of the NE. The NE is not "just talk" or simply rhetoric but, also, includes the everyday actions of Catholics at all levels of the church as their faith becomes real through what they do. Here we turn attention to the practices of devotional prayer, parish meetings (and other types of meetings), and service as key foci of the NE. To 
miss these practices would be to miss where "the rubber meets the road" or where the talk becomes walk - really the center of the NE as a lived reality.

Theoretically, we draw on Durkheim[7], Bellah[8], and Rawls' work ([1],[9]) on enacted "practices" in social/religious life without delving deeply into their positions and arguments which are beyond the scope of this paper. Nevertheless, they have influenced the methodology and theorizing about the NE herein. Secondly, qualitative data on NE practices coalescing around devotional prayers, parish meetings, and Christian service activities associated with the NE will be presented. Finally, from a theory of practices perspective, some conclusions are made about the observed practices linked to the NE.

\section{Theory of Social Practices}

Following Rawls and Bellah, this study assumes Durkheim did not privilege beliefs over practices. Indeed, Rawls has spent much of her sociological career explaining how Durkheim has been misinterpreted in this regard, especially by Parsons[1]. Bellah, for his part, has relied on Rawls in this regard and agrees with her. As Bellah has noted: "Anne Warfield Rawls has usefully emphasized what she calls "concrete practices," that is actual bodily movements, as the basis of Durkheim's theory of ritual [practices]. It was her article, "Durkheim's Treatment of Practice: Concrete Practice vs. Representation as the Foundation of Reason" [9] that called this passage [Durkheim's passage in book 11, chapter 5 - about bodily movements] to my attention" (2005: 208). Bellah goes on to say that it was in this key chapter of Durkheim's that we learn that ritual (practice) is prior to belief and, moreover, gives rise to belief. Rawls, indeed, has argued that Durkheim's argument is about mutual intelligibility achieved through orders of practice. Durkheim, in other words, formulated a classic epistemological argument, in his book Elementary Forms of Religious Life[7], against Kant's categories of the understanding as being $a$ priori; but rather these categories of the understanding were created first through social ritual practices of the community. Durkheim thus elaborates a theory of practice as the basis of mutual intelligibility and consequently as the epistemological basis for the discipline of sociology.

Collective representations or "beliefs," on the other hand, are essential in the process of society becoming aware of itself, but these beliefs arise from and express the homogeneous physical movements or practices that constitute the practices/ritual, not the other way around. Thus Durkheim does not advocate a "symbolic interpretation" of ritual practices as if ritual practices are only about expressing meaning of some belief of the community. For Durkheim, social enactment/practices are primary and they cannot be reduced to the symbols that derive from it. As Rawls notes:

In arguing that religion played an essential role in establishing a shared knowledge base, Durkheim was rejecting existing approaches to the problem of knowledge, replacing explanations that began with the individual with his own socially based argument that knowledge is created by the shared experience of enacted practices. His argument privileges enacted social practice over beliefs and ideas, an innovation that avoids dilemmas inherent in philosophical

approaches to knowledge and morality that are based on individualism, and the privileging of beliefs and ideas over practices; both dominant tendencies in western thought (2004: 3).

Ideas then are retrospective accounts of practices - theory arises at sunset as the ancients said. Nevertheless, although practices are the foundation of knowledge, ideas and practices are in an intimate relationship - a sort of back and forth. Catholics' practice of Eucharist, for example, makes one feel more like a Catholic afterwards, but also in learning more about the theology (idea) of the Eucharist many want to practice the Eucharist more wholeheartedly. Specifically, there is a back and forth synchronicity of sorts between practices and belief. Which came first, practices or ideas, is still a legitimate question but one not answered here. But for Durkheim, in making his epistemological argument, at the beginning of time practices came first, then ideas about those practices arose or retrospective accounts. This research argues, however, for a both/and situation in which enacting some "practice" might motivate people to rethink their lives as well as "ideas" possibly motivating people to engage in certain practices. Hence, practices can stimulate new ideas and/or ideas have the potential to stimulate new practices. Rawls does argue that ideas play a very important role in maintaining and continuing practices but are nevertheless secondary.

Regardless of the both/and framework, Durkheim's emphasis on practices forces certain questions to surface. For example, are there NE practices? Or, are the practices observed in the field simply ordinary ecclesial practices to which the NE label gets attached? In other words, is the NE a purely ideological movement to which any number of ecclesial practices are associated ([10]? Are devotions really a NE practice? Are parish meetings a NE practice? Are service projects a NE practice? Again, is there such a thing as a NE practice per se or do seemingly regular ecclesial practices of prayers, meetings, and service projects get clumped under a new heading called the NE? Given the prevalence of the Catholic Charismatic Renewal's association with the $\mathrm{NE}[2]$, do Catholic Charismatic practices simply find a new home under the ideological roof of the NE? Are there any practices that have given rise to the $\mathrm{NE}$ and/or are there any practices that the NE has given rise to? Furthermore, if the $\mathrm{NE}$ is an internal ecclesial movement[11], perhaps in reaction to Vatican II, is the NE 
then mostly ideological, theological, and discursive rather than issuing forth new bodily practices? The next section, then, delineates the practices observed in studying the implementation of the NE in parishes and other settings qualitative data - after which some answers to the questions above are presented.

\section{Practices and the New Evangelization}

\subsection{Devotional Prayer: Individual and Communal}

As observed since 2005 through field research and through surveys[12],[13], the NE in practice is closely tied to devotional prayer[6],[14]. At least in the United States, this is somewhat of a turnaround of a trend that was moving away from devotional practices. "Lay Catholic devotional practices...started to decline in the 1950s and continued after Vatican II (1962-1965)" [6],[13] and [14]While Melissa Wilde [15]believes the emphasis on ecumenism at the Second Vatican Council had something to do with the decline in Catholic devotional practice, this research has found that the NE has prompted an increase in Catholic devotions. And while an assumed chain of causation could be that of the rise of the NE leading to the rise of devotional practices, the data here suggest that an increase in prayer and devotional practices is a force giving rise to NE discourse. This assertion needs further investigation but it does follow a logical chain that begins with specific practices, which then are retrospectively accounted for via discourse and policies, as a Durkheimian perspective would predict. Stephen Warner has recently formulated this same argument but about music: "I do not sing sacred harp music because it is meaningful to me; it is meaningful to me because I sing it"[17],[18].

Other observations of a turn to devotional prayer in metropolitan Detroit include the installation of a prayer chapel at St. Agatha's (parish and priest names changed confidentiality) in 2006, an increase in devotional prayer to the saints at St. George's, the opening up in 2008 of 24 hour Eucharistic Adoration and a Holy Hour / Eucharistic Exposition at St. Philip's, and the memorization of prayers among some young people. Around the time NE workshops were in full swing at St. Agatha's, a move was made to build an entirely new chapel as a result of, and in order to facilitate further, devotional prayer through Eucharistic Exposition and Adoration. Some parishioners at the time stated that the money for the chapel would be better spent on helping parishes in Detroit or on social justice causes but this more communal perspective was not embraced (field notes 2005-2009). To prioritize devotional practices appeared at that time to be one of the basic distinctions between NE oriented professionals and those who thought more in terms of the Second Vatican Council - so-called Vatican II professionals[2],[11]. Observations of a similar upswing in devotions in other parishes around the Archdiocese of
Detroit, including at St. George's and St. Philip's (field notes 2005-2009), were readily made as well. Memorization of prayers among some people may also be on the rise as one young priest noted. This young priest, Fr. Thad, described a situation in which some older Catholics he was interacting with were surprised that he could recite by heart the prayer to St. Michael. ${ }^{1}$

While the train of causation that could easily be embraced here is that the rise of the NE coming from Rome has led to the rise of devotional practices, these data here suggest a different interpretation. While not denying that the actions, policies, and rhetoric coming from Rome have direct and powerful effects on the Catholic faithful (especially certain church professionals), it is suggested nevertheless that devotional prayer was actually already a stable Catholic practice but with the rise of the NE is receiving a new surge of emotional energy to, in particular, promote and sustain a personal relationship with Jesus. One poignant image of this is of John Paul II walking through the mountainside with rosary in hand. Although the waning of devotional practices both individually and at the parish level since Vatican $\mathrm{II}^{2}$ have not completely disappeared, John Paul II and the NE have instilled a renewed recognition and emotional fervor that has advanced and further encouraged individual devotional prayer both at home and at the parish.

\subsection{Meetings: Informal and Formal}

Perhaps it goes without saying that any movement or effort involving groups of people will require those people meeting. Yet, the particular details of what those meetings were or are can be essential to understanding the dynamics of the movement. In fact, both formal and informal meetings have been essential and key for the advance of the NE. This short article cannot detail all of what these meetings are, were, or may be, but nevertheless, a few examples will suffice to illustrate what is needed here.

First is a conversation that took place between the Ann Arbor / Detroit based lay leader Ralph Martin and the late John Paul II as reported to the author by Mr. Martin himself in 2007. Pope John Paul II had called lay leaders of various lay movements in the Church to come to Rome to discuss with him their ministries. When it was Mr. Martin's turn to speak to the Pope, Mr. Martin at some point in the conversation mentioned his new book, and the Pope said, "yes, I have read it." And then the Pope asked Mr. Martin, "what would you say is the essence of your book?" Mr. Martin, after a few thoughtful seconds, said

RM: It's essence is Jesus.

JPII: Yes, Jesus.

1 Related, see also McCallion \& Bennett-Carpenter[18] on "displays of faith."

2 A common observation or truism is that among Vatican II professionals strict Catholic devotional practices went by the wayside in favor of a spirit of ecumenism/community rather than promoting the individual focus of devotions. 


$$
\begin{array}{ll}
\text { RM: Yes, Jesus. } \\
\text { JPII: Jesus. } \\
\text { RM: Jesus. } \\
\text { JPII: Jesus. }
\end{array}
$$

Perhaps at this point in time such an account may or may not be surprising, while just a few years ago such an account would sound to most Catholic people fairly shocking coming from a Roman Catholic pope and not an evangelical Protestant evangelist such as Billy Graham. But by now, with the NE arguably in full swing, and with its emphasis on Jesus as central - specifically having a "personal relationship with Jesus" as noted earlier - such an interchange appears merely exemplary for what characterizes the NE - having a personal relationship with Jesus. Moreover, Ralph Martin has reported that this conversation with John Paul II was a catalyst for him to do what he could to advance the NE in Detroit, the United States, and internationally. ${ }^{3}$ Indeed, it could be argued that Ralph Martin, now Dr. Martin (2010), is one of if not the leading lay figure in the United States promoting the NE with considerable world-wide influence (he attended the Synod on the New Evangelization in Rome in 2012 as one of the few USA representatives).

Many examples of self-organized networks of people could be given as examples of meetings observed during this research, and more examples will be cited in a moment, but one meeting that has a strong charismatic flavor is the St. Paul's meeting at Sacred Heart Major Seminary in Detroit. This is a more or less informal get-together on Fridays in something like a seminar format that includes prayer, sometimes someone who may speak, but mostly just to talk about what is on people's hearts and minds. Certainly, as just mentioned, these meetings have a strong Catholic Charismatic flavor to them in that much witnessing of Jesus' action in people's lives occurs as well as speaking in tongues. There are also the innumerable casual conversations that take place in the cafeteria, between classes, in the library, and in people's living quarters that end up driving some of the primary lines of speech and thought with a strong individualistic or personal relationship with Jesus flavor, for what is formalized as the NE. Although these meetings are communal gatherings, a powerful individualistic tone and emphasis prevails - an emphasis legitimized by the theology of the NE.

The St. Paul meetings described above had the most direct individualistic emphasis of all the meetings observed in the study, but the meetings with perhaps the greatest impact or influence (although this impact still needs further study) were the meetings of the parish evangelization committees ([11],[19] and [20]). Most of the parish evangelization committees observed were committees instituted in the name of the NE -- even though most refer to them as simply evangelization committees. Earlier publications of these data

3 In part, this also encouraged a change in the Catholic Charismatic Renewal movement, in that the CCR was being, in part, "repackaged" in terms of the New Evangelization. show the increase in the number of parish evangelization committees between the years 2005 and 2013 - growing from $17 \%$ of parishes having an evangelization committee in 2005 to $30 \%$ having one in 2013. In some cases these committees formed as a natural outgrowth of self-organized groups of lay and professional Catholics, inspired by what Vatican II had proclaimed about evangelization, but as mentioned earlier most committees were formed at the encouragement of the Detroit archdiocese and Pope John Paul II's insistence on a NE.

These committees are in fact just one example of a vast number of groups of Catholics around the world that seem to have claimed a renewed sense of what they take to be a life led by the Gospel, many of which arose during the pontificate of JPII. As we have described elsewhere,

Professionals and lay leaders during John Paul II's pontificate and afterwards have taken [the] personalistic emphasis [of JPII] as a new lease on life of faith for Catholics. His writings, person, and charisma have been drawn upon directly in a massive effort from many different circles that now are institutionalizing his legacy and are continuing in the pontificate of Benedict XVI. With groups such as Opus Dei, the Legionaries of Christ, Comunione e Liberazione, the Neocatechumanent Way, Focolare, and the Community of Sant'Egidio identified as part of the NE Movement (McBrien 2008), the institutionalization of John Paul II's call for a New Evangelization is being manifested. ...Moreover, many ecclesial communities, men's and women's groups and conferences, and media/internet-based venues are revealing the extent of the NE, which demonstrates forms of religious connection within a global society that are both transnational and local ([22],[23]). ([2], p. 307; also see [24]p. 4).

Following...emerging social networks, the scope of the NE movement in the Catholic Church also appears to include many ecclesial communities throughout Latin America and elsewhere, thousands of men's and women's groups emerging around North America, including large men's and women's conferences, and television, radio, and internet-based media venues such as EWTN, the Catholic Channel on SIRIUS radio, and the Catholic Exchange (catholicexchange.com). Linked by an extensive social network, these New Evangelization Catholics are attempting to bring about a new movement in relation to the Catholic Church that would...make the Second Vatican Council (Vatican II) appear to history as ... a precursor to NE Catholicism.... ([2]p. 292)

Women's and men's groups have been especially big in Detroit, with the men's groups in particular drawing very large crowds of several thousand at the University of Detroit Mercy's basketball arena (Field notes 2005-2009). The Alpha program also has become popular in relation to the NE 
in the many Catholic parishes. Importantly, one of the key practical elements of the NE is the fact that in large measure the main efforts are being spearheaded and moved forward by ambitious lay leaders, drawing upon resources close to their own lives as they live them, with then priests, bishops, and popes coming on board and carrying it forward one way or the other. Nevertheless, these meetings are packed with personal witnessing of the power of Jesus in various individual's lives. Again, the individual is emphasized in these communal settings.

Another key set of meetings that must be mentioned is the first Synod on the NE called by Pope Benedict XVI and held in Rome in October 2012 as mentioned ealier. This meeting or set of meetings, along with the resulting Apostolic Exhortation (Evangelii Gaudium [5] [The Joy of the Gospel]) issued by Pope Francis in 2013, was the most high profile and explicit recognition and institutionalization of the NE to date. Bishops from all around the world descended on Rome, as they customarily do for such meetings, in the name of what is being here interpreted as the church's primary "policy" or mission strategy since the Vatican II era. As a result of this International Synod on the NE, the Archbishop of Detroit has called for an Archdiocesan Synod in 2016.

Although the actual experiences of the NE on the ground are more complex than what is going to be presented next, the pattern suggested below has nevertheless been a regular and consistent observation in this study. Specifically, and especially in considering the next NE practice, Christian service, a shift was observed revealing a movement away from a heavily individualistic emphasis in the NE starting in 2005 to a more communal emphasis in 2013. In other words, individual devotional prayer (while not excluding communal prayer and practices) laid the groundwork of, and has become a hallmark of the NE in the early years of its implementation. Data further reveal that this same individual emphasis continues in devotional prayer and meetings that have become associated with the planning of the Archdiocesan synod. Both of these practices, that is devotions and meetings, lean heavily in an individualistic direction especially in that both are legitimized by the powerful rhetoric of having a personal relationship with Jesus. Moving forward in time, however, in light of the newest pope, Francis, field interview data suggest that part of the future of the NE appears to be turning its attention increasingly toward Christian service through a greater emphasis on welcoming, charity, and social justice. Data suggesting this more communal emphasis are presented next.

\section{Christian Service: Charity and Social Justice}

It is difficult, impossible really, to innumerate individual acts of private charity where "the left hand does not know what the right hand is doing". And while these happen and it is important to acknowledge these are happening, examining what is in fact happening by both individuals and groups that are attempting to advance the well-being of other human beings who are suffering can be seen and enumerated. However, to date, this study shows that most calls to social justice and Christian service are identified with the calls and spirit of the Second Vatican Council. While charity and voluntarism certainly is identified with the era of the papacy of John Paul II, perhaps most emblematically portrayed in the example of Mother Teresa, the emphasis tended toward individual piety and toward justice being meted out person to person. This was reinforced with the "personal relationship with Jesus" language as noted above. Yet it was John Paul II that bolstered the language and action of "solidarity" (including the actual Solidarity movement in Poland), and under John Paul II and Benedict XVI the work of Catholic Charities, Catholic Relief Services, and all the Christian Service projects in parishes carried on as a mainstay and primary thrust of the Catholic church's mission. It has not been until recently that all of these efforts have been drawn into the language of the NE, at least for the study herein.

The full discussion of how this happened and its dynamics are a discussion for another time, yet I speculate that what could be happening now or in the near future is that a third primary practice associated with the $\mathrm{NE}$, along with devotional prayer and meetings, is or will be service. The scope and depth of Catholic service efforts through parishes, Catholic Charities, Catholic Relief Services, and innumerable Catholic organizations and individuals throughout the world is difficult to quantify. The efforts of Catholic Charities in the USA, for example, are massive and second only to the federal government. Need one mention Catholic hospitals and schools? Robert Calderisi in a recent book, Earthly Mission: The Catholic Church and World Development[25], outlines some of what he sees as the highlights of the church worldwide in its efforts to make the world a better place. It is interesting to see how all these efforts may be subsumed within or merged with the NE, as Pope Francis did in Evangelii Gaudium [5].

There, among other things, Pope Francis begins with an emphasis on the "joy" of all those who "encounter Jesus" (1). "I invite all Christians everywhere, at this very moment, to a renewed personal encounter with Jesus Christ" (3), the pope writes. Yet, even as this personal invitation to "encounter Jesus" frames the whole discourse of what comes next, the major attention then turns to the mission of the Church (Chapter 1) which is communal (Chapter 2), includes everyone in its proclamation (Chapter 3 ), and is primarily social (Chapter 4). All of this is wrapped up in the language of being "spirit-filled evangelizers" (Chapter 5), with Mary cited as the "Star of the New Evangelization." In a nutshell, "new evangelization" as an ideograph, sign, or word-symbol is employed by Pope Francis here to reintroduce, encourage, and heavily freight the NE in a social, communal direction in terms of service to others.

Linguistically, moreover, Pope Francis speaks more frequently of an "encounter" with Christ than a "relationship 
with Jesus" which is notable both theologically and sociologically. Specifically, it is hypothesized that this language change is moving the NE discussion in a more communal direction because, in particular, Pope Francis' address at the general audience at St. Peter's Square on 25, June, 2014 articulated this quite clearly:

We are able to live this journey not only because of others, but together

with others. In the Church there is no "do it yourself", there are no "free agents".

How many times did Pope Benedict "describe the Church as an ecclesial "we"'!

At times one hears someone say: "I believe in God, I believe in Jesus, but I don't

care about the Church...". How many times have we heard this? And this is not

good. There are those who believe they can maintain a personal, direct and

immediate relationship with Jesus Christ outside the communion and the

mediation of the Church. These are dangerous and harmful temptations. These

are, as the great Paul VI said, absurd dichotomies. ..."

Theologically, the language of mediation moves the discussion toward the fundamental Catholic principle of mediation or principle of sacramentality. It is "in and through" (principle of mediation) the sacraments that we encounter Jesus Christ and God's grace of salvation. Moreover, Pope Francis' discussion of the Mission of the Church emphasizes the communal dimension of Catholicism and its social concern for the poor. Sociologically, it could be argued that under Francis' papacy the individualistic NE emphasis of a personal relationship with Jesus is moving toward a larger social solidarity with the poor, the mission of the Church and the world - it is a "communal relationship with Jesus" rather than primarily a "personal relationship with Jesus."

Speculating further, remembering Durkhiem's emphasis on enacted practices, Pope Francis' highlighting welcoming and social justice practices (communal and mission dimensions of the NE), is presenting the Church with an even more powerful means of advancing the NE than the previous practices focused on devotions and meetings. Why? Because he is appealing to another group of Catholics, call them communal Catholics, than the previous NE that emphasized a "personal relationship with Jesus." Pope Francis is not eliminating the personal empahsis but expanding it and consequently, it is believed, more Catholics will climb on board the NE because it will reinvigorate the communal Mission of the Church. As suggested above, however, perhaps devotions and meetings needed to occur first in time before the NE could blossom more fully as a mission Church or as Pope Francis stated it in "Joy of the Gospel," a field hospital (a Church of welcome and social justice). Therefore, it is suggested, that Pope Francis is advocating a more practice oriented Church rather than one that simply talks about evangelization and having a personal relationship with Jesus. Indeed, there is a popular summary of the last three popes that goes something like the following: Pope John Paul II told us "what" to do, Benedict XVI told us "why" we should do it, and Pope Francis is telling us to "do it."

In terms of data from the field, it was regularly noted in phone calls to parishes asking them whether or not they had a NE committee, which approximately $50 \%$ of the parishes that said NO also said "we already do that with our Christian Service and/or RCIA." Without going deeply into data collected on this point, more and more Christian service coordinators in parishes were found to be discussing their parish ministry in terms of the NE, especially since the papacy of Francis. Much of what they said could be summarized as follows: "doing Christian service is the NE, it is just a non-verbal means of evangelizing. We are doing it rather than just talking about it." Helping others as a means of evangelizing has a more communal feel and dimension to it than the other emphasis on having a personal relationship with Jesus.

\section{Discussion and Conclusions}

Durkheim's theory of enacted practices influenced this study's basic question: are there NE practices? This question directed the study's focus away from theology, theory, and discourse about the NE to enacted practices, bodily movements, or bodily emotional impact of the NE. With this focus, the NE enacted practices of religious devotions, meetings, and Christian service activities were observed as paramount bodily enacted practices. Moreover, this focus brought to light much of the tension and conflict encountered in the field between various professional ecclesial ministers, as briefly noted earlier. Another way of stating this is to say that when it came to "practices" there was little conflict but when it came to discussing "ideas" about the NE (which occurred mostly with professionals) conflict was prevalent. Nevertheless, thinking with Durkheim, what conclusion can be made about devotions, meetings, and services tied to the NE?

All three of these practices have received a new energy because the NE has acted as a new legitimizing ideological force for doing these activities. Indeed, as suggested about service practices, the NE is moving towards more concrete practices after much discussion and theologizing about it in the earlier years of its implementation in the AOD. Consequently, one conclusion about these activities is that they are not so much "NE practices" as they are "practices" that have received a new bolt of legitimizing energy from the theology of the NE. As earlier research shows, the average Catholic in the pew does not know what the NE is and when asked in a survey if they have ever even heard of it only $7 \%$ declare they have[10]. But these same Catholics, many anyway, are quick to acknowledge that they are "proud to be 
Catholic," perhaps more so than in the recent past.

In the end, this study does not confirm Durkheim's epistemological argument about the primacy of practices over ideas, but it does conclude that enacted practices linked to the NE have moved from an individual into a communal direction based on observing practices. The empirical data suggests, therefore, that the NE does legitimize and encourage some Catholic practices more than others - such as concrete devotional practices. In doing so the NE has done much in the way of enhancing Catholic "proudness", an emotional enhancement, more so than in creating specific NE social ritual practices, a behavioral enhancement, among ordinary Catholics. Perhaps Pope Francis' emphasis on mission or the social/communal will carve out new ground for professionals and laity alike to advance their faith in relation to the NE. It is very likely that this communal emphasis will continue with Pope Francis but it is also likely that conflict will continue among NE and Vatican II professionals over this very emphasis.

Finally, it is asked, so what if the NE is moving in a more communal direction under Pope Francis? One "so what" might be that more Catholics will be invigorated to be reunited with the church - so called communal Catholics or social justice Catholics. This assumes that the NE as a "personal relationship with Jesus" was too narrow a focus for communal Catholics yet attractive for some Catholics, especially those Catholics with a charismatic sensibility. Another "so what" is if the communal emphasis does not receive emotional fueling from the $\mathrm{NE}$ like the individualistic "personal relationship with Jesus" did and still does, then it will not have the impact or effect on Catholics and non-Catholics as suggested it will. Pope Francis needs to talk the talk, walk the walk, and rock the rock - that is affectively line up his emotions about the communal NE with his rhetoric and behavior - which he appears to be doing in a powerful way. Behaviorally, the NE has devotional practices, etc. (walk the walk); cognitively, the NE legitimizes or fuels these practices with theological ideas (talk the talk); and affectively the NE is actually fueling these practices with emotion or emotional energy or as JP II said: with new ardor and conviction (rock the rock). As Shalin writes: "We know what it means to talk the talk and walk the walk, but this dyad is incomplete without the third leg - to Rock the Rock. Those unwilling or unable to sweat it out, to assume a proper bodily stance and generate a believable affective display, risk having their performances doubted" ([26]204). The movement toward the communal needs to be believed affectively, there must be believable, convincing emotional displays of helping the poor and doing justice which show these practices are right and just affectively and cognitively. Especially in today's contemporary culture do the people of God and the world at large need to see the hierarchy of the church actually living this out affectively, behaviorally, and cognitively. What is new about the NE then is not so much "new practices" but the fueling of already in place Catholic practices with new ardor and vigor.

\section{REFERENCES}

[1] Rawls, Anne Warfield. 2004. Epistemology and Practice: Durkheim's The Elementary Forms of Religious Life. Cambridge: Cambridge University Press.

[2] Bennett-Carpenter, B., \& McCallion, M.J. (2012). Specialized, ecclesial ideography: The <new evangelization $>$ in the Catholic church. Michigan Academician, XLI(1): 1-21.

[3] McCallion, M.J., Bennett-Carpenter, B., \& Maines, D.R. (2012). Individualism and community as contested rhetorics in the Catholic New Evangelization movement. Review of Religious Research, 54(3): 291-310. DOI:

10.1007/s13644-012-0069-y

[4] Smith, Christian, Brandon Vaidyanathan, Nancy Tatom Ammerman, Jose Casanova, Hilary Davidson, Elaine Howard Ecklund, John H. Evans, Philip S. Gorski, Mary Ellen Konieczny, Jason A. Springs, Jenny Trinitapoli, and Meredith Whitnah. 2013. "Roundtable on the Sociology of Religion: Twenty-Three Theses on the Status of Religion in American Sociology_A Mellon Working-Group Reflection”. Journal of the American Academy of Religion, PP. 1-36.

[5] Francis, Pope. (2013, November 24). Evangelii gaudium [Apostolic exhortation]. Washington DC: United States Conference of Catholic Bishops.

[6] McCallion, M.J. (2014, February 4). The social dimension of the New Evangelization [blog posting]. On The Catholic Conversation: From a Sociologist's Perspective blog for the University of Notre Dame Blog Network. Retrieved fromhttp://blogs.nd.edu/thecc/2014/02/04/the-social-dimensi on-of-the-new-evangelization/on 19 February 2014.

[7] Durkheim, E. 1912 / 1995. The Elementary Forms of Religious Life. Translated by Karen Fields. New York: Free Press.

[8] Bellah, Robert. 2005. "Durkheim and Ritual." In The Cambridge Companion to Durkheim. Edited by Jeffrey C. Alexander and Philip Smith. Cambridge: Cambridge University Press.

[9] Rawls, Anne Warfield. 2001. "Durkheim's Treatment of Practice: Concrete Practices vs. Representation as the Foundation of Reason." The Classical Journal of Sociology, 1(1): 33-68.

[10] Bennett-Carpenter, B., \& McCallion, M.J. (2013). <Personal relationship with Jesus $>$ : A popular ideograph among evangelical Catholics. Journal of Communication and Religion, 36(1): 1-24.

[11] McCallion, M.J. (2014). The New Evangelization in the Archdiocese of Detroit as an intra-ecclesial social movement. Church Life: Culture and the New Evangelization, 2(4): $23-40$.

[12] McCallion, M.J., and Bennett-Carpenter, B. (2009). Survey on the New Evangelization in six parishes in the Archdiocese of Detroit. Unpublished data/report. 
[13] McCallion, M.J. 2015. The New Evangelization in the Roman Catholic Archdiocese of Detroit, Michigan: A Sociological Report. Lewiston: The Edwin Mellen Press.

[14] McCallion, M.J. (2012a, May 17). Catholic devotions. [blog posting.] The Catholic Conversation: From a Sociologist's Perspective blog posting for the University of Notre Dame Blog Network. Retrieved from http://blogs.nd.edu/thecc/2012/05/17/catholic-devotions/ on 31 October 2013

[15] Kelly, T. 1994. "Suburbanization and the Decline of Catholic Public Ritual in Pittsburg." Journal of Social History.” Winter, Volume 28: 311-330.

[16] Wilde, Melissa J. (2007). Vatican II: A sociological analysis of religious change. Princeton: Princeton University Press.

[17] Warner, Stephen R. 2007. "2007 Presidential Address: Singing and Solidarity." Journal for the Scientific Study of Religion, 47(2): 175-190.

[18] Luhrmann, T.M. (2012). When God talks back: Understanding the American evangelical relationship with God. New York: Vintage.

[19] McCallion, M.J., and Bennett-Carpenter, B. (2008). Displays of faith: Material/visual versus cognitive/verbal. Review of Religious Research, 49(4): 427-437.

[20] McCallion, M.J. (2012b, February 15). Catholic new evangelization: Who has even heard of it? [blog posting.] The Catholic Conversation: From a Sociologist's Perspective blog posting for the University of Notre Dame Blog Network. Retrieved from

http://blogs.nd.edu/thecc/2012/02/15/catholic-new-evangeliz ation-who-has-even-heard-of-it/\#more-591 on 31 October 2013.

[21] McCallion, M.J. (2012c, May 7). The new evangelization and its institutionalization in the Catholic church. [blog posting.] The Catholic Conversation: From a Sociologist's Perspective blog posting for the University of Notre Dame Blog Network. Retrieved from http://blogs.nd.edu/thecc/2012/05/07/the-new-evangelization -and-its-institutionalization-in-the-catholic-church/ on 31 October 2013.

[22] Vasquez, M.A. and Marquardt, M.F. 2003. Globalizing the Sacred: Religion Across the Americas. New Brunswick, NJ: Rutgers University Press.

[23] Wuthnow, R. and Offutt S. 2008. "Transnational Religious Connections." Sociology of Religion 69:2: 209-232.

[24] Peterson, A., Vásquez, M, \& Williams, P. 2001. Introduction: Christianity and social change in the shadow of globalization. In Peterson, Vásquez, \& Williams (Eds.), Christianity, social change, and globalization in the Americas, pp. 1-22.

[25] Calderisi, R. 2013. Earthly mission: The Catholic church and world development. New Haven: Yale.

[26] Shalin, D.N. 2011. Pragmatism and Democracy: Studies in History, Social Theory, and Progressive Politics. New Brunswick: Transaction Publishers. 